\title{
CLOCK TOWERS AS THE FOCUS OF CITY SQUARE: THE CHANGING SCALE OF NUSRETIYY CLOCK TOWER
}

\author{
Elif GELMEZ \\ İstanbul Kültür University, Turkey \\ orcid.org/ 0000-0003-0190-6296 \\ e.gelmez@iku.edu.tr \\ Meriç ALTINTAŞ \\ İstanbul Kültür University, Turkey \\ orcid.org/ 0000-0003-1171-0297 \\ m.altintas@iku.edu.tr
}

\begin{abstract}
Tophane, with its historical and cultural heritage, is acknowledged to be one of the most significant districts of Istanbul. Formerly known for its gardens, the district has acquired a different identity after the Ottoman conquest of Istanbul in 1453. Tophane-i Amire, being the imparial armory which was established in the Ottoman period did not only name the region, but also altered the social and cultural profile of the district to a great extent. The region has suffered the great fires of Istanbul and been damaged many times by them, thus the architectural texture it possesses had undergone many changes both due to these disasters as well as political and governmental adjustments of the authority. In time, the growth and continuous territorial expansion of Ottoman dominion necessitated the innovations and advancements in the military along with the construction of additional buildings to the Tophane facilities. Together with the additional buildings, the area had once again acquired a distinct identity where civil and military architectural examples coexist. Following the effects of industrialization seen in the late 19th century, the escalating growth of the city, beginning in the early 20th century, has reached levels that prevent the perception of the integrity among Tophane facilities. After 1950, the starting of customs house constructions and the expropriation policies had changed Tophane beyond all recognition. Being completed in the second half of the 19th century, Nusretiye (Tophane) clock tower is known to be the first clock tower of Istanbul. During the period of its construction, the clock tower had been in the center of the military drill field, defining a circumferential open space by itself. However, due to the expropriation policy of the 1950s, it was taken to another spot where the customs buildings had been located. With this study, a brief examination of Nusretiye clock tower has been conducted to understand its relation to the surroundings with a projection from past to present. To analyze and discuss the established relationships in depth, the Tophane Square and the Tophane Barracks, as architectural representatives of the region and era, were also included in the scope of the study. The study aimed to reveal and present the current conditions of the clock tower, to remark the significance of the surrounding architectural interactions in the perception of an architectural heritage and to discuss the effects of the changes made to the Tophane district.
\end{abstract}

Keywords: Tophane, Nusretiye Clock Tower, Istanbul, Architecture, Expropriation, Tophane Barracks, City Square

\section{KENT ODAĞI OLARAK SAAT KULELERİ: NUSRETIYE SAAT KULESINIIN DEĞIŞEN ÖLÇEĞİ}

\section{ÖZ}

Tophane, İstanbul'un tarihi birikimi yüksek semtlerindendir. Önceleri bahçeleriyle bilinen semt İstanbul'un fethiyle farklı bir kimlik kazanmıştır. Osmanlı döneminde kurulan Tophane-i Amire bölgeye adını vermekle kalmamış semt profilini büyük ölçüde değiştirmiştir. Bölge İstanbul yangınlarından zarar görmüş içindeki mimari doku dönem dönem değişikliğe uğramıştır. Zamanla 
Osmanlı Devleti'nin büyümesi, yapılan askeri alandaki yenilikler, Tophane binasına ek binalar yapılması gerekliliğini beraberinde getirmiştir. Böylece bölge askeri yapıların birlikte bulunduğu yer olmuştur. 19. yüzyıl sonlarında sanayileşme etkileri görülmüştür. 20. yüzyıl başlarında şehir, Tophane yapılarının bütünlük algısını engelleyecek düzeyde büyümeye başlamıştır. 1950 sonrası, gerek gümrük binalarının inşaasına başlanması gerekse istimlak politikaları Tophane'nin tanınamayacak hale gelmesine neden olmuştur. 19.yüzyılın ikinci yarısında yapımı tamamlanan Nusretiye (Tophane) Saat Kulesi İstanbul'un ilk saat kulesidir. Yapıldığı dönemde talimhane meydanını odağındaki kule, 1950 yıllarındaki istimlak politikası sebebiyle bulunduğu yerden taşınmış gümrük binalarının bulunduğu alana alınmıştır. Tophane Saat Kulesinin çevresiyle ilişkisini çözmek için, içinde bulunduğu Tophane Meydanı ve Tophane Kışlası da çalışmada incelenmiştir.Bu çalışmayla yapının günümüzdeki durumunu anlatmak, çevresinin bir yapıyı algılamadaki önemine dikkat çekmek ve yapılan değişikliklerin Tophane semtine etkilerini incelemek amaçlanmıştır.

Keywords: Tophane, Nusretiye Saat Kulesi, İstanbul, Mimari, Kamulaştırma, Tophane Kışlası, Şehir Meydanı

\section{INTRODUCTION}

Tophane is located in the European side of Istanbul, where the Bosphorus meets the Golden Horn. It is a district of Beyoğlu and lies between Karaköy and Fındıklı. Today, the district acts as a junction point for the public transportation network; the available tram, ferry, subway, and bus stops on the region trigger an intense human circulation passing through everyday. Istanbul Modern Art Museum, the Turkish Maritime Enterprise, the ongoing Granit Center Museum Building and various hotels are among the buildings that are lined up along the Tophane coastline.

Tophane-i Amire, Nusretiye Mosque, Tophane Square and Fountain, Tophane Summer Palace and Nusretiye Clock Tower are among the Tophane facilities that were able to survive to the present day. The construction of the Nusretiye Clock Tower, which constitutes the subject of this study, was completed in the second half of the 19th century and had defined an open space - a city square - used as the training area of the Tophane Barracks at the time. The square had also been considered as one of the entrance gates of the city that the sultans of the Ottoman Empire had been using while returning from the sea. The statesmen, the embassies and the travelers of the day were welcomed here and the area was used for artillery shooting during drills and celebrations. Today, the clock tower remains in the entrance garden of the Istanbul Modern, a contemporary museum established in 2004, and surrounded by other constructions.

\section{A Short History}

\section{History of Clock Towers}

The need for humankind to understand time has emerged with the settled communities of the first farmers. For the pioneering agricultural societies of the period, it was crucial to keep track of the seasonal changes in order to comprehend the crop planting and harvesting periods and thus, act accordingly for the accuracy of production. This demand had led to the emergence of observable time technology. It is assumed that early efforts regarding the understanding of time had started possibly between the years of 2000-3000 BC with the use of easy-to-access materials such as water, sand, or by examining the apparent position of the Sun, its movement and other star movements (Acun, 2011:3). ${ }^{1}$ At first, the early societies in China, India, Mesopotamia and Egypt had been using a system formed by the movement of the Sun. This system has enabled to monitor the movement of the Sun, therefore time, by measuring the length of the shadow casted by a bar that is erected on the ground. Sundials are generally either constituted of a specially prepared rod (gnomon) placed upon a marble, stone or metal flat plate (the dial); or integrated to the monumental structures in various centers of residential areas

\footnotetext{
${ }^{1}$ Initially a simple rod (gnomon) and a mechanism of using sun movement were developed. Night time, water hour and hourglass were used for situations where they could not benefit from sunlight. The water hour is measured by the discharge time from the hole of the container filled with water, while the hourglass is based on the system formed by the flow of sand in the cabinet. Night time, however, emerged by examining the movements of the known stars (Akbulut, 2010: 28).

Submit Date: 07.11. 2017, Acceptance Date: 12.12.2017, DOI NO: 10.7456/10801100/008
}

Research Article - This article was checked by Turnitin

Copyright (C) The Turkish Online Journal of Design, Art and Communication 
(Salman , 2009: 17). ${ }^{2}$ In the light of the information acquired from Herodorus, it can be stated that the Hellenes had acquainted the knowledge of measuring time using the sun from Egyptian and Mesopotamian civilizations. The Romans, on the other hand, began to use sundials starting from 164 BC, with an appropriate system adopted according to the latitudes of their own cities (Salman , 2009: 19). Since Islamic worship has been firmly tied to the notion of time, sundials have become more precise and convenient in the Islamic countries (Acun, 2011: 3).

In addition to the sundials invented to tell the time, other devices that are called usturlab (astrolabe) and rubu were also being used for similar purposes. Usturlab is a time measuring and direction finding tool based on the Moon movements designed by Hipparchus, a Greek astronomer, geographer and mathematician in the 2nd century BC. The device was further developed towards the end of the Ancient Age and was advanced by the Arab-Islamic states in the 8th century. Ebû Abdullah Muhammed el-Battânî, an Arabic astronomer and mathematician, measured 1 solar year to be 365 days, 5 hours 46 minutes and 24 seconds using usturlab, that is indeed a quite close measurement to the present data. With the ongoing Crusades during the 11th and 13th centuries, the interactions between European and Asian civilizations led to the escalation of many knowledge and scientific work carried on into Europe (Koca, 2015: 11). ${ }^{3}$ The clocks called usturlab and rubu are the oldest systems close to today's mechanical clocks.

The mechanical clocks initially appeared in Europe as of facade, cathedral and city square clocks. The earliest clock towers known were in churches and palaces, built in 13th century in Westminster, England and Padua, Italy. The astronomical clocks, however, began to be used in the years of 1300 (Acun, 2011: 5-6). These clocks, which did not possess hour and minute hands to begin with, were heavy by means of their structure and were designed to strike the correct time only. Their duty was to show the movement of the Sun, the Moon and other stars with the help of additional dial plates and gears. It is known that the public would had examined the zodiac displayed on the plates and performed their daily tasks accordingly. Today, there are very few examples of such medieval astronomical clocks remain standing (Gürbüz, 2009: 134).

The clock towers, in addition to being a monument and symbol of the region, were also committed to preserve the communities' well-being whilst being used as fire and observation towers. Therefore, they have been placed on the facades of important public buildings as well as on noticeable hills and focal points where they would have been distinguished.

\section{Clock Towers in the Ottoman Empire}

The significance of sundials inherited from the Mesopotamian and Egyptian civilizations, has increased with the emergence of Islam. Considering the strict connection established and dependence on time, the ritual worships and religious fasting devotions have been a motivation source for the development of the sundials by the Islamic scholars. The leaders of the Islamic States have separately calculated the prayer times for their state borders. Following the Ottoman conquest of Istanbul, Fatih Sultan Mehmet appointed a civil servant for the calculation of the prayer times (Meyer, 2009: 30).

In addition to the sundials that often appear on the walls of mosques, in the common areas of the palaces and the madrasahs, the usturlab and the rubu plates have also been used widely. The sundials, usturlab and rubu which had continued to develop during the period of Anatolian Seljuk Empire and Ottoman Empire had been continuously used until the 20th century. As a consequence of the accelerated developments in the technology however, they have not been able to sustain their presence against the increased use of mechanically wound clocks.

\footnotetext{
${ }^{2}$ In the Byzantine period, a gnomon belonging to the 4th century, was brought from the Amon Temple in Karnak, Egypt, and used in the Constantinapolis Hippodrome during its period. The obelisk located in the Sultanahmet Square, today, is an example of a gnomon belonging to the 4th century. (Bir ve Kaçar, 2010: 33).

${ }^{3}$ Thus, in 1436 Frenchman Jean Fusoris made the first 'usturlab' in Europe (Koca, 2015: 11).
} 
The earliest studies and works performed on mechanical clocks have been made during the Ottoman Sultan Mahmud II period (Acun, 1994: 4). The on display mechanical clock collections of Topkap1 Palace Museum are among the world's remarkable clock collections.

Although the clock towers were present in Europe during the 14th century, the construction of the clock towers in the Ottoman Empire was found to be commenced in the 16th century. This fact asserted by Kienitz, can be corroborated by the architectural evidences of the Banyaluka Ferhat Pasha Mosque Clock Tower and the Skopje Clock Tower, which are known to date back the 16th century. Evliya Çelebi's Travelogue is also another source that mentions the clock tower in Skopje (Acun, 1994: 5).

In 1901, it is known that the Ottoman Sultan Abdulhamid II had enacted an edict to the governors of every province regarding the building of clock towers. Following the edict, there had been a significant increment in the number of clock towers in Istanbul and Anatolia. An art historian, writer and the only woman in Turkey who master the restoration of ancient Turkish mechanical clocks Şule Gürbüz has stated the following in regards to the matter;

"... Working hours, operational organization of transport and relevant timetables have begun to be arranged in accordance with the alafranga time while the clock towers were built one after the other. It is also the reason that the clock towers were called 'hometown clock' at that time. It is also part of these exercises that the two faces of the four-facade clocks were set to alaturca and the other two were set to the alafranga; and over time, in 1925, the alaturka clock was completely abolished (Gürbüz, 2009a; 143) ..."

After the year of 1926, the clocks were adjusted to a new system in consideration of the Gregorian calendar and Alafranga clock practices. Together with the Turkish Alphabet reform, some clock dials of the clock towers have been replaced by Latin numbers, while others have continued to be used with Arabic numerals (Acun, 1994: 6). ${ }^{4}$

The clock towers in Istanbul and Anatolia were much simpler when compared to their European counterparts. They were lower in height and had an architectural structure that is in harmony with the urban fabric. The clock mechanisms used were of English or French origin.

\section{A Brief History of Tophane District}

Tophane has been home to many civilizations throughout the ages and the region has been known by different names in different eras. To begin with, in ancient times, the region was called Incirlik (Skyaena). At that time, the Galata region had contained the area known as Tophane today. Galata was a small town surrounded by ramparts, hosting one hammam, one theater, five mills, four hundred houses and forty city guards in total. In the Byzantine period, the region was named Gümüss Şehir (Argyropolis), which means silver city in the Turkish language, and the region was regarded as fields and gardens though some sources refer to it as a forestland. It was during the Byzantine period that the church of Irene was built upon where once the Temple of Apollo had been located. After the Ottoman conquest of Istanbul though, the same area hosted the construction of the Ottoman Empire cannon foundry, namely Tophane-i Amire (Tunç, 2004, s.11). As in most cases, it was the arsenal from which neighborhood derived its name; Tophane. Among many of the historical city gates of Istanbul located on the Galata walls there is one gate, which opens to the region and was also entitled as Tophane Gate, with a reference to the arsenal once again (Ceylan, 1998, s.43). It is a known fact that Tophane-i Amire was not the pioneer foundry in the Ottoman period, much older arsenal facilities were located in Edirne and other localities. However, in that period, the repute of Tophane-i Amire was essentially implying the arsenal established in the Tophane district of Istanbul and apart from that, the terms like Tophane-i Galata and Tophane-i Dergah-l Ali were also used to indicate the armory building in Istanbul.

\footnotetext{
4 "...Alaturka hour system is a time measuring system that the Turkish community had been using for centuries, adjusting themselves, their affairs, the whole order of their life accordingly. Alaturka predicates the sun position to tell the time. As the sun is changing everywhere according to the longitudes, Alaturka clocks change from city to city. [...] Alaturka time does not offer a standard time measuring system (Gürbüz, 2009b: 59)
}

Submit Date: 07.11. 2017, Acceptance Date: 12.12.2017, DOI NO: 10.7456/10801100/008

Research Article - This article was checked by Turnitin

Copyright (C) The Turkish Online Journal of Design, Art and Communication 
Fatih Sultan Mehmed's first action after the conquest of Istanbul was to get the arsenal and the Dımışkihane $e^{5}$ built (Tunç, 2004: 20). The arsenal in this period had three domes (Aydüz, 2011a: 11), and Evliya Çelebi used the term 'a small building' for the arsenal which was established during this period. Through the reign of Fatih Sultan Mehmet, Mehmed the Conqueror, the construction processes continued increasingly, and during the period of Bayezid II (1481-1512), the barracks were added next to the arsenal. However, it is stated that a neighborhood has emerged just after a century from the beginning of the constructions (Tunç, 2004: 13). During the reign of Kanuni Sultan Süleyman, Sultan Suleyman the Magnificent (1520-1560), all of these facilities were demolished and replaced with much larger and new cannon foundries (Image 1). In 1719, these wooden structures were completely destroyed in the fire and consequently, did not survive the present day (Tunç, 2004: 24; Aydüz, 2011: 16).

The assertion that the ruined buildings had not been altered until the reign of Sultan Mahmud I (17301754), is also confirmed by the lack of documentation of this issue. In 1743, the currently existing Tophane-i Amire building was constructed by Mustafa Aga, an artilleryman, who was also an artisan of the time (Image 2) (Aydüz, 2011: 16). It was during this period that the Tophane square had first extended via the riprap works (Güncüoğlu, 2009: 12). On the shoreline, there were always cannonballs on display that were either pillaged trophies or placed for training purposes (Image 3). The cannon foundries and barracks burning in the Mahmud I period were restored during the Mustafa III period (1757-1774) and a masjid ${ }^{6}$ was added alongside of these facilities (Güncüoğlu, 2009: 12).

In the second half of the 18th century, Tophane had aroused interest among foreign countries. The ambassadors, pilgrims, travelers and explorers of the era brought architects and painters with them to draw engravings of Istanbul. By this means, a great amount of sources had reached the present day (Güncüoğlu, 2009: 12).

Tophane district had gone through significant changes during the Selim III period (1789-1807); the reforms had excessive impacts on both the state and the city. The guild of Janissaries ${ }^{7}$ was replaced with the establishment of Nizam-i Djedid ${ }^{8}$, the regular army, which led to an increase in military structures. The military training of the army established in this period had came into prominence, therefore, three buildings parallel to each other were built on the shoreline of Tophane and put to use as barracks (Image 4). The exhibited cannonballs were removed and the area was reserved for military training (Güncüoğlu, 2009: 13-15). Furthermore, opposite the Nusretiye Mosque, Imalat-ı Harbiye Usta Mektebi ${ }^{9}$ was built in the 19th century (Güncüoğlu, 2009: 64).

In the second half of the 19th century, the construction of the Nusretiye Clock Tower was completed (Tunç, 2004: 14). The clock tower was located in front of the Tophane Barracks and to the south of Nusretiye Mosque built by Mahmud II (Acun, 2011: 39).

These collective facilities of Tophane had lost their influence after the World War I. The abandoned buildings were left to be ruined over time; they had lost their architectural integrity with the expansion of the city (Güncüoğlu, 2009: 29). The city expansion had affected not only the architectural fabric of Tophane but as well as the human profile (Aktay, 2013: 117).

After 1950, as a result of the road construction works and the expropriation policies of the time, the coastline was obstructed; both the Tophane Barracks and the Imalat-ı Harbiye Usta Mektebi of the period were totally demolished. Today, the two foundries and the Nusretiye Clock Tower remain to be the only survivors. Following the fire in 1913, the Nusretiye Clock Tower was removed from its place,

\footnotetext{
${ }^{5}$ The military factory where swords were made during the Ottoman period.

${ }^{6}$ A Muslim place of worship.

${ }^{7}$ (New soldiers, or Troop) The elite infantry corps that formed the Ottoman Sultan's household troops.

8 Turkish meaning: "The new order"

${ }^{9}$ A military school to train officers in the Ottoman Army.

Submit Date: 07.11. 2017, Acceptance Date: 12.12.2017, DOI NO: 10.7456/10801100/008
}

Research Article - This article was checked by Turnitin

Copyright (C) The Turkish Online Journal of Design, Art and Communication 
that is near the Nusretiye Summer Palace, and transferred due to the road construction works in 1950s (Cansever, 2009:133). The clock tower which has been moved up to the customs warehouses, is currently located in the backyard of the Istanbul Modern, and its surroundings are being used as storage areas.

\section{Tophane Facilities and the Square Talimhane ${ }^{10}$ and the Square}

The Turkish Language Institution ${ }^{11}$ defines the term "meydan"12 as free space, field; a place for competition, entertainment, and meeting [1]. Another definition for "meydan" is a place with a particular landscape area or covered with flooring; having a rectangular shape, and being partially or completely surrounded with buildings (Büyükcivelek, 2012: 342). Apart from its lexical meaning, it is necessary to perceive what "city square" means in Turkish culture as compared to the Western world. In Turkey, from open spaces to junctions where roads intersect, a variety of places can be referred as "square". In Western cultures however, "square" defines the subject of this study whereas "space" defines mostly the notions of open space or place. The city squares, generally, are not open on all sides, indeed, are almost enclosed spaces with monumental and historic structures around them (Taşçı, 2014: 104).

Talimhane is surrounded by the Nusretiye Mosque, Tophane Barracks and Tophane Summer Palace, which are also located around the Nusretiye Clock Tower. Talimhane addressed in this study corresponds to the "city square" description by Taşçı, therefore, the open space defined by Talimhane was also considered as another city square within the scope of this study.

During the reign of Selim III, all the trees around Talimhane, including some houses as well, were chopped down and demolished in order to make room for the young soldiers of Nizam-i Djedid troops to receive military training. The proudly displayed trophies of cannonballs were removed from the tree bottoms of the Tophane Square, so that the area can be allocated to the instruction of Nizam-i Djedid troops (Tunç, 2004: 15). The area reserved for Talimhane between the years of 1847-48 in front of the Tophane-i Amire building was expanded by the expropriation of some workplaces. In addition to the artillery shooting, the very first testing of the newly produced cannonballs were made in this area.

Talimhane was located on the seashore where the Tophane Pier was thus, the incoming foreigner guests would first encounter with the square (Image 5). Until the Galata Pier was built in 1894, the Tophane Pier was the major pier of the period and was frequently used for arrival and departure to Beyoğlu. It was surrounded by high trees and Kılıç Ali Paşa Mosque was visible from the shore. The ambassadors had also been using the Pier regularly to reach the Topkapı Palace (Tunç, 2004: 13).

\section{Tophane Barracks}

An ambitious effort of military reform was launched during the reign of Selim III, geared towards securing the Ottoman Empire. In conjunction with the establishment of Nizam-1 Djedid troops, military training was given a great notice thus, the cannonballs laid out in the Tophane Square were removed, the trees were cut off, and the area was prepared for its utilization in military training (Image 20). Another adjustment made during this period was the relocation of the Gun Carriagers Barracks ${ }^{13}$ from Ahırkap1 to Tophane. All these modifications, ultimately, had created the need of constructing new buildings (Güncüoğlu, 2009: 28-29).

In 1789, the Tophane Barracks was built at the behest of Selim III (Aran, 1995: 279). The barracks was composed of three parallel buildings at the seashore, with floors gradually increasing in number. Rising on two floors above the ground level, the building was naturally lightened through its rectangular windows arranged side by side on the facade (Image 6). The barracks located between the

\footnotetext{
${ }^{10}$ Military training field.

11 Türk Dil Kurumu (TDK).

12 A commonly used Turkish word for "square".

${ }^{13}$ Top Arabacıları Kışlası.
}

Submit Date: 07.11. 2017, Acceptance Date: 12.12.2017, DOI NO: 10.7456/10801100/008

Research Article - This article was checked by Turnitin

Copyright (C) The Turkish Online Journal of Design, Art and Communication 
foundry and the sea had two gates; one facing the north, the other the sea. The one facing the sea was much larger and ornamented than the other (Tunç, 2004: 29).

The building block fronting the sea has expanded seawards at its ground floor. Beneath the first floor that formed the cantilever, an arcaded structure ${ }^{14}$ was composed by a series of columns (Image 7). Following the column axis of the arcaded structure, there were built-in columns that continue up to the eaves. In the midst of these building blocks, there was a single-domed and single-minaret mosque built for the barracks. The mosque was damaged in Firuzağa Fire and instead, the Nusretiye Mosque was constructed in 1823, which is still in use today (Güncüoğlu, 2009: 29).

The plain appearance of the barracks facades had been jazzed up with gradually rising floors. Despite the common preferences in barracks architecture with courtyards, the Tophane Barracks was quite different from the precedents of its era. Even so, the slight movement of the left side of the facade towards the sea is conformed with the conventional barracks architecture. The area underneath the cantilever was purposed as a boathouse to be used by the Sultan (Image 8) (Aran, 1995: 279).

These buildings which provide accommodation for the artillery soldiers were mostly constructed in wood therefore, they were often burned down and reconstructed repetitively again and again. During the years of 1863-1864, the buildings had suffered a fire, and Abdülaziz had ordered for the construction of the Military Marshalcy Building on the place of the destroyed building, extending the area towards the Imalat-ı Harbiye Usta Mektebi (Güncüoğlu, 2009: 28).

\section{Nusretiye (Tophane) Clock Tower}

Nusretiye Clock Tower was named after the neighboring Nusretiye Mosque and is the oldest clock tower of Istanbul (Cansever, 2009: 133). Currently, the tower is located to the south of the Nusretiye Mosque, which was built during the reign of Mahmud II; whereas initially, it was constructed by the sea as demonstrated in the engravings (Image 9). The Sultan's signature above the southern window indicates that the tower was built by the command of Sultan Abdulmecit in 1848-1849. Goldwin suggests that the structure belongs to Bali Balyan (Acun, 1994: 18).

The structure has a square plan with the edges measured to be 4,35 meters at the ground level and gradually narrows with these square cross-sectioned floors as it rises up. The three rows of eaves divide the 15-meters high structure transversally into four floors (Cansever, 2009: 133).

The ground floor is surrounded by four columns placed at corners, independent of the facade. The gates located between the Doric columns are high and arched with a rounded top. A palmette motif can be detected on the outgoing keystone. The armorial bearing (Coats of Arms) belonging to the Ottoman Sultan Abdülmecid is worn out on the facade facing the sea. The first floor is surrounded at the corners by the grooved, built-in columns with Ionic heads. For the windows on the facades, arches in Baroque style were used. The second floor is dominated by framed wreaths and herbal ornaments at the corners. The thin eaves of this floor is carried via small consoles. On the last floor there are four clocks. These watches are covered with leaded tunnel vaults. Sphere-shaped stones placed in corners are found in larger dimensions on the ground floor (Tunç, 2004: 14).

When the clock tower was built, there was a pike on the tower to draw flags during the ceremonies. Yet today, this component has disappeared. The clock tower, which had suffered a fire in 1923, currently serves as a warehouse (Image 10) (Güncüoğlu, 2009: 24).

\section{0s: Before and After}

After the World War I, the military buildings had lost their significance; the civilian architectural majority resulting from the rapid population growth has triggered the loss of the architectural integrity among the military facilities (Image 11) (Aydüz, 2011: 30). Still, the buildings in Karaköy-Kabataş

\footnotetext{
${ }^{14}$ Riwaq.

Submit Date: 07.11. 2017, Acceptance Date: 12.12.2017, DOI NO: 10.7456/10801100/008

Research Article - This article was checked by Turnitin

Copyright (C) The Turkish Online Journal of Design, Art and Communication
} 
area, being one of the social, military and administrative heart of the Ottoman capital city, Istanbul, had preserved their existence with very minor changes until the 1950s.

After the establishment of the Republic, Ankara was assigned as the capital city and most of the urban studies had focused on there, and then it was Istanbul's turn to come. Due to these reasons, H. Prost was invited by the Turkish government in 1934 to prepare a comprehensive Istanbul master plan. Although some works of Prost, who stayed in Istanbul for 16 years (1935-1951), were given the opportunity to be implemented in some regions, most of the proposals had not been applied at all (Aydemir, 2008: 106-107).

While Aydemir declared that the Prost plans were not put into practice because of the World War II, a report titled as "Yurdumuzda İmar Çabalar1 ${ }^{15 "}$ was published by the Chamber of Architects of Turkey addressing that the Prost's proposals had been criticized and the referral committee has been appointed to the task in 1952. According to the report, unplanned demolitions and regulations were made to intervene the prepared plan by the delegation. It was stated that a holistic development plan that can deal with the entire city while protecting its historical characteristics was not achieved. Eventually, the routes of the Prost plan were partially expanded and arbitrary routes were added in some places (Aydemir, 2008: 107 ; Esmer, 2013).

The Prime Minister of the period, Adnan Menderes, had directly supervised the development plan and expressed his views on the subject at the press conference held on September 24, 1956, in order to give information about the new construction works:

"Our desire is to enliven the Istanbul's historical character and its great monuments, as well as the treasures hidden behind the ruins and to reveal them as to put them showcase. [...] Since a city without its beautiful and large squares can not be conceived, all the squares of Istanbul will be worthy of its glory and surrounded by large buildings. For example, Karaköy, Eminönü Square will be like this. [...] Beşiktaş Square on the way from Karaköy to the Bosphorus along the coast will be made into a true square and given either a name of Preveze or Barbaros. The great road from Yildiz will also come down to the axis of this square." (Esmer, 2013)

However, when it came to 1956, the project started under the name of "İstanbul Development Plan" and the history of Istanbul was ignored. During the course of the work, most of the historical monuments were dismantled or subjected to regional devastation. Approximately 10,000 houses have been expropriated and destroyed. Narrow pedestrian paths and surroundings were often transformed into 70-80 meter wide unplanned streets (Altunel - Ertem, 2011: 63).

In this period, along with the Taksim Military Barracks of Tophane, Imalat-ı Harbiye Usta Mektebi, the Military Marshalcy Building and the courtyard of the Nusretiye Mosque were completely demolished, and the Sultan Abdul Hamid II Fountain was relocated (Image 12) (Altunel - Ertem, 2011:70).

The Nusretiye Clock Tower was built in the years of 1848-49. The tower had suffered a severe fire in 1913 , and was moved in front of the customs warehouses leaving its actual place nearby the Nusretiye Summer Palace (Cansever, 2009: 133). The tower, currently located between the customs buildings and the area where once the hookah cafés were, is now neglected between the Istanbul Modern building and the construction works near the museum.

In 2006, the area of the demolished Imalat-l Harbiye Usta Mektebi was declared a renovation area. However, the experts state that due to the lack of building survey related to the building, the reconstruction efforts would not reflect the reality (Image 13) (İnce, 2013).

\section{CONCLUSION}

During the last stages of the Ottoman period, the Tophane district was actively used by the reason of its proximity to Dolmabahçe Palace thus, it had witnessed serious historical events (Picture 14-15-16-

15 The Efforts of the Restoration in Our Country.

Submit Date: 07.11. 2017, Acceptance Date: 12.12.2017, DOI NO: 10.7456/10801100/008

Research Article - This article was checked by Turnitin

Copyright (C) The Turkish Online Journal of Design, Art and Communication 
17-18). The Nizam-1 Djedid army established by Selim III had practiced their military trainings in this square and important negotiations of the period had taken place in Tophane Summer Palace. The Tophane facilities were reflecting the characteristics of the 18th and 19th century Ottoman military buildings whilst naming the region and preserving its urban fabric. The year of 1963 was when the first tram voyage was held here.

Today, only a few of the buildings surrounding the Tophane Square remain standing. With the demolitions that has started in 1956, Tophane had lost its identity and with the customs buildings that were constructed, the connection of the region with the sea was cut off (Image 19). Indeed, Tophane's history has been forgotten. In respect thereof, Aydın Boysan said the following: "[...] As if the Old Istanbul was sliced. [...] A new Istanbul has collapsed over the old city of Istanbul and buried it. Those still visible from the Old Istanbul are the grave stones of the buried city."

Regardless of its many tourist attractions such as mosques, fountains, madrasahs, barracks; this region has evolved into an irregular, incompatible, disorganized, and fragmented state that is far from being able to tell the tale of that era as a whole. As a result of this situation, the Tophane district has transformed into yet another ordinary region that was rarely visited or just passed through (Image 20) (Altunel-Erdem, 2011: 74).

The historical region, which was important from a military, administrative and social perspective once, can not reflect the traces of that period anymore. It is known that the demolition works carried out in the region before were motivated by the need for a city square and an increased vehicle density of the near future. Obviously, these problems still cannot be solved today.

Kostof collects functions of the squares under five main headings. These are; the squares that are part of the transport system (Piazza del Poppolo in Rome, for example), the squares with commercial activities and urban functions, the squares defined by administrative functions and religious structures, the squares where entertainment and ceremonial events are held, and the squares surrounded by small businesses where their owners live on their upper floors, namely residential squares. In the past, the squares with the administrative functions were used as a sort of armory display area as in Place d'Armes. Horse Guards Parade in London is yet another example for tour de force. Here, the purpose of the display of weapons or the law enforcement forces is to prevent the any possible events that will shake the authority while giving assurance to the public on the one hand (Büyükcivelek, 2012: 342). As a symbol of power, the Russian army makes a traditional demonstration of power in the Red Square, which is surrounded by government offices (Büyükcivelek, 2012: 345).

The Talimhane Square of Tophane has served this purpose since its first day. This was an influential field where the Nizam-i Djedid army was trained, new weapons were tested and the leaders of other nations were welcomed. The expansion of the square has defined the square once the construction of the Nusretiye Clock Tower was completed, which was initially built by the sea side during the reign of the Ottoman Sultan Abdülmecid. Considering the riprap works and the demolishing of much of the buildings on the square where it was inhabited, there was no longer a square to delineate. During the expropriation policies in the 20th century, the Nusretiye Clock Tower gibiililgi çekmewas moved and took its place in the entrance garden of today's Istanbul Modern (Image 21).

As seen from the engravings and paintings, the clock tower was the focus of the square, arousing interest for people using the water transportation and landing there. As a focal point of the square, the clock tower was in harmony with the surrounding buildings and all together they had created urban fabric. The architectural integrity of buildings in the square had created unity and formed an appropriate city square coherent with its function. Today, it is difficult, even impossible, to detect the Nusretiye Clock Tower due to the disproportionate growth around it (Image 22).

"The city may mean a square from another perspective." This phrase from Kilıçbay asserts the intertwined relationship between city and square, as the two terms resemble each other. The squares describe the cultures and habits of the community as well as characterizing it. They allow to transfer and cherish the historical accumulations in a community (Taşç1, 2014: 105-106). 
Today, consumption-oriented public spaces (shopping malls, etc.) tend to change the meaning of publicity. This causes deep changes in people's understanding of socialization. The cities that preserved the squares they had built in the past could stop these negativities to some extent because, they had protected their heritage and values (Büyükcivelek, 2012: 345).

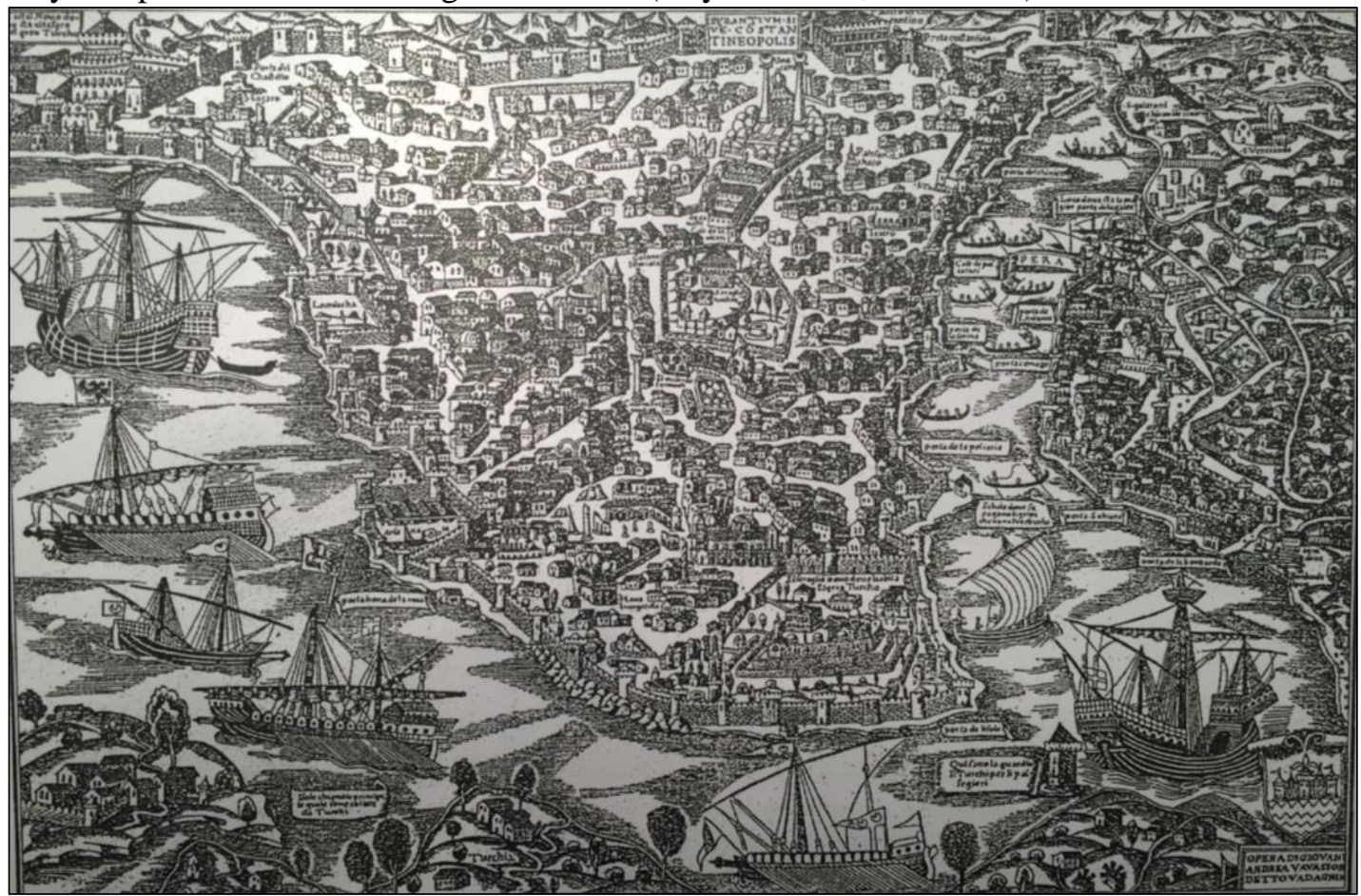

Image 1: At the beginning of the 17th century an engraving depicting Istanbul (Tunç, 2004: 71).
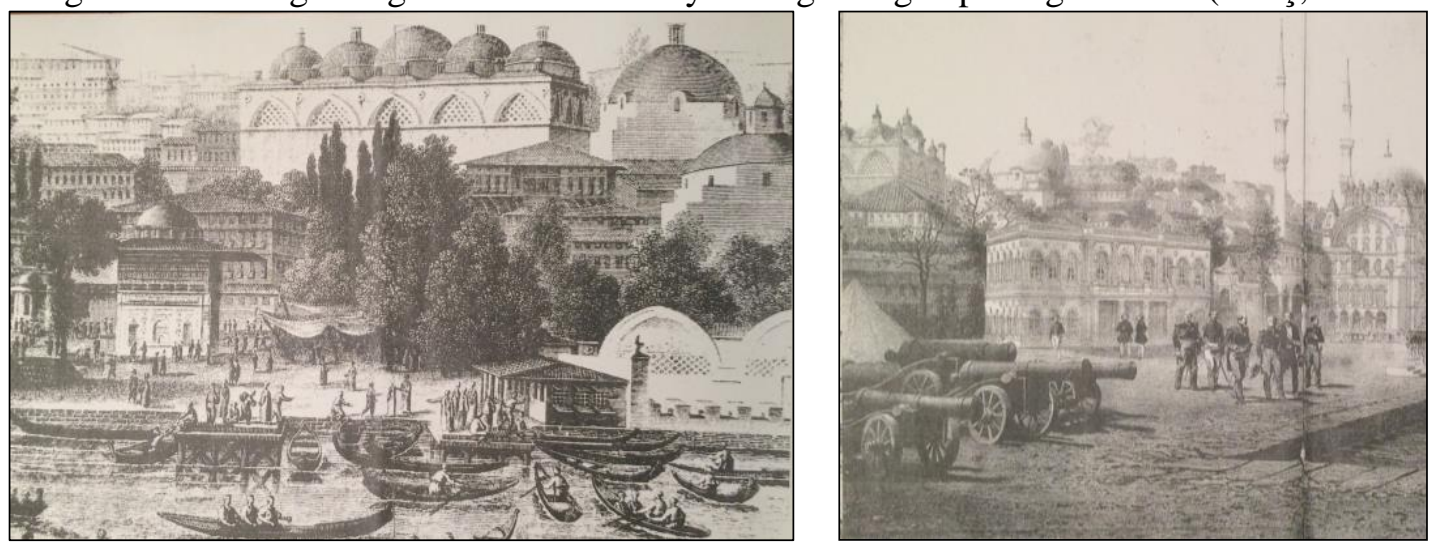

Image 2: Melling's engraving work in 1819. Facade of Tophane-i Amire (left) (Gülersoy, 1971). Image 3: Engraving depicting of guns in 1856 (right) (Gülersoy,1971).

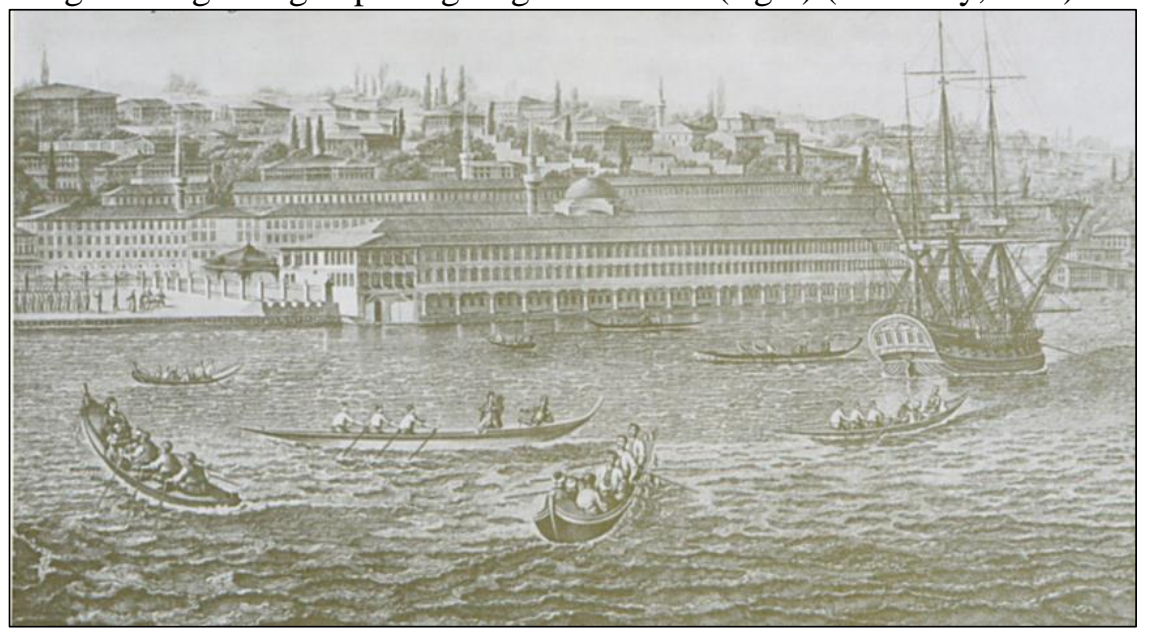

Submit Date: 07.11. 2017, Acceptance Date: 12.12.2017, DOI NO: 10.7456/10801100/008

Research Article - This article was checked by Turnitin

Copyright $\odot$ The Turkish Online Journal of Design, Art and Communication 
The Turkish Online Journal of Design, Art and Communication - TOJDAC

ISSN: 2146-5193, January 2018 Volume 8 Issue 1, p.79-96

Image 4: Melling's engraving in 1809. (Güncüoğlu, 2009: 7)

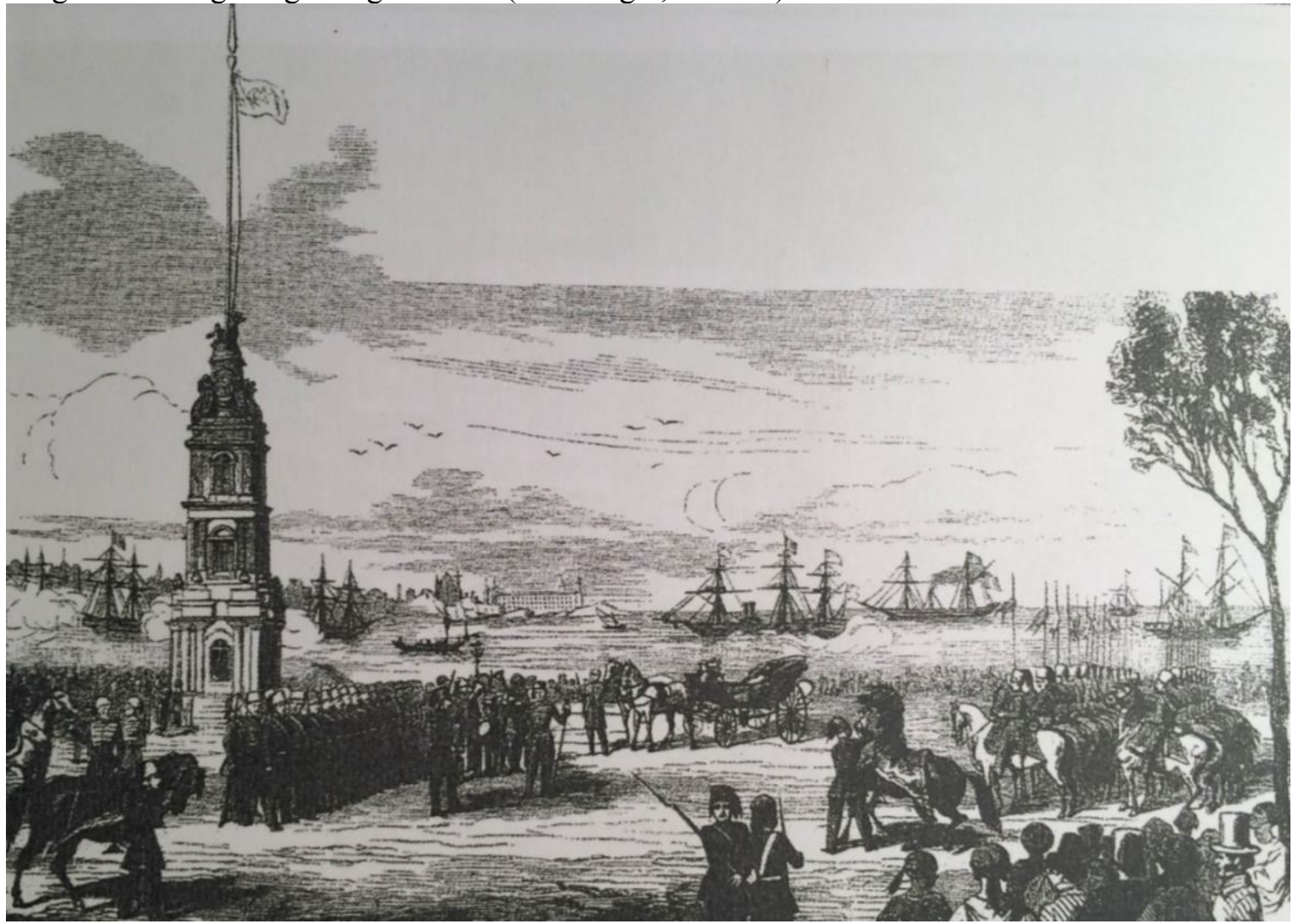

Image 5: Preparing to meet Prince Napoleon in Tophane. Engraving drawn by Jean Brindes. (Tunç, 2004: 115)

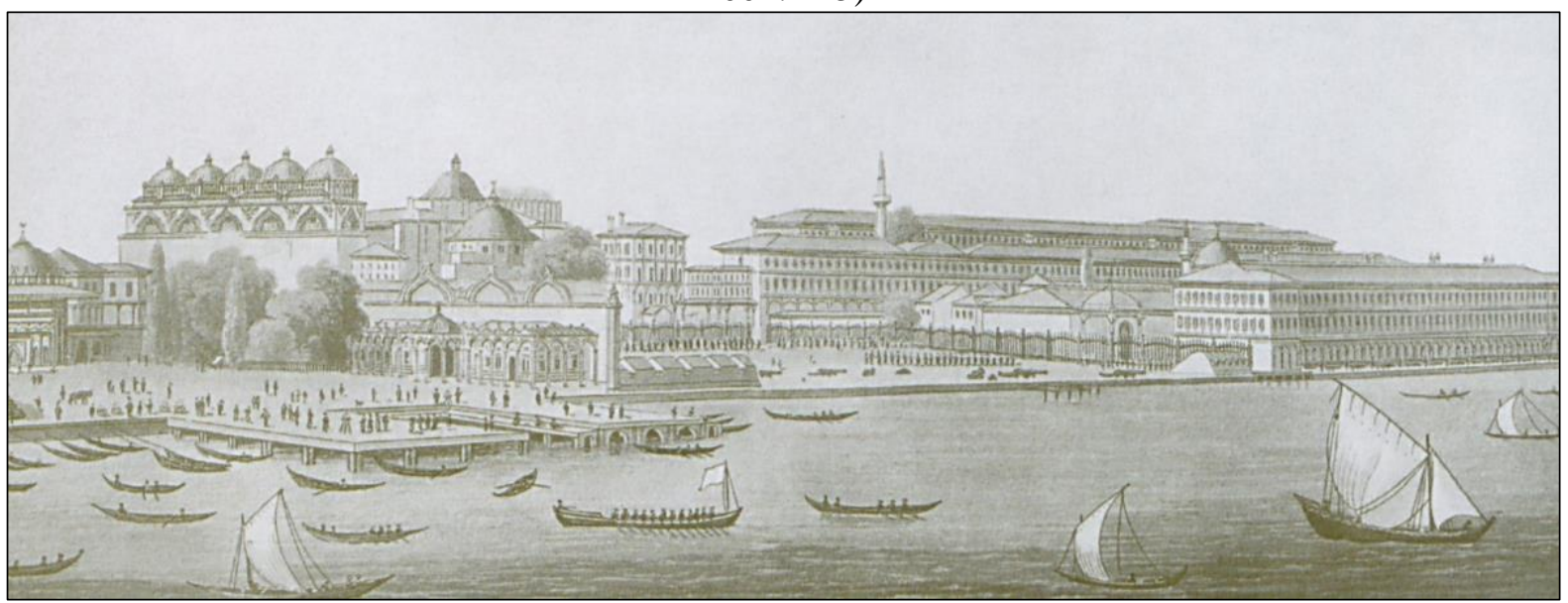

Image 6: Engraving drawn by Jon Cam Hobhouse in 1813 (Güncüoğlu, 2009: 10).

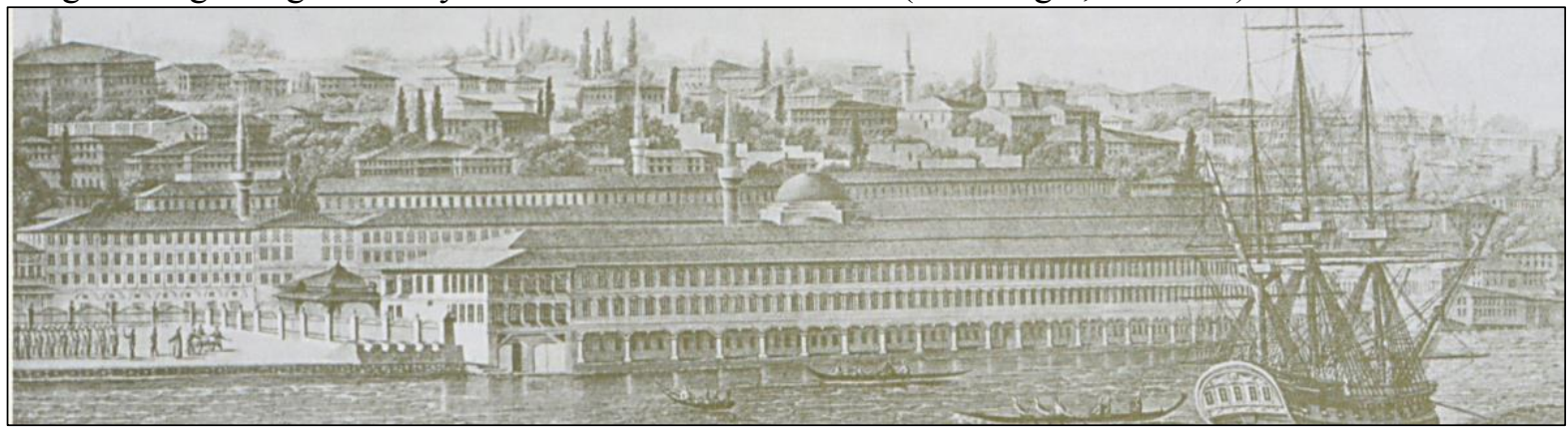

Image 7: 19. yüzyıla ait gravür (Gülersoy,1971). 
The Turkish Online Journal of Design, Art and Communication - TOJDAC ISSN: 2146-5193, January 2018 Volume 8 Issue 1, p.79-96
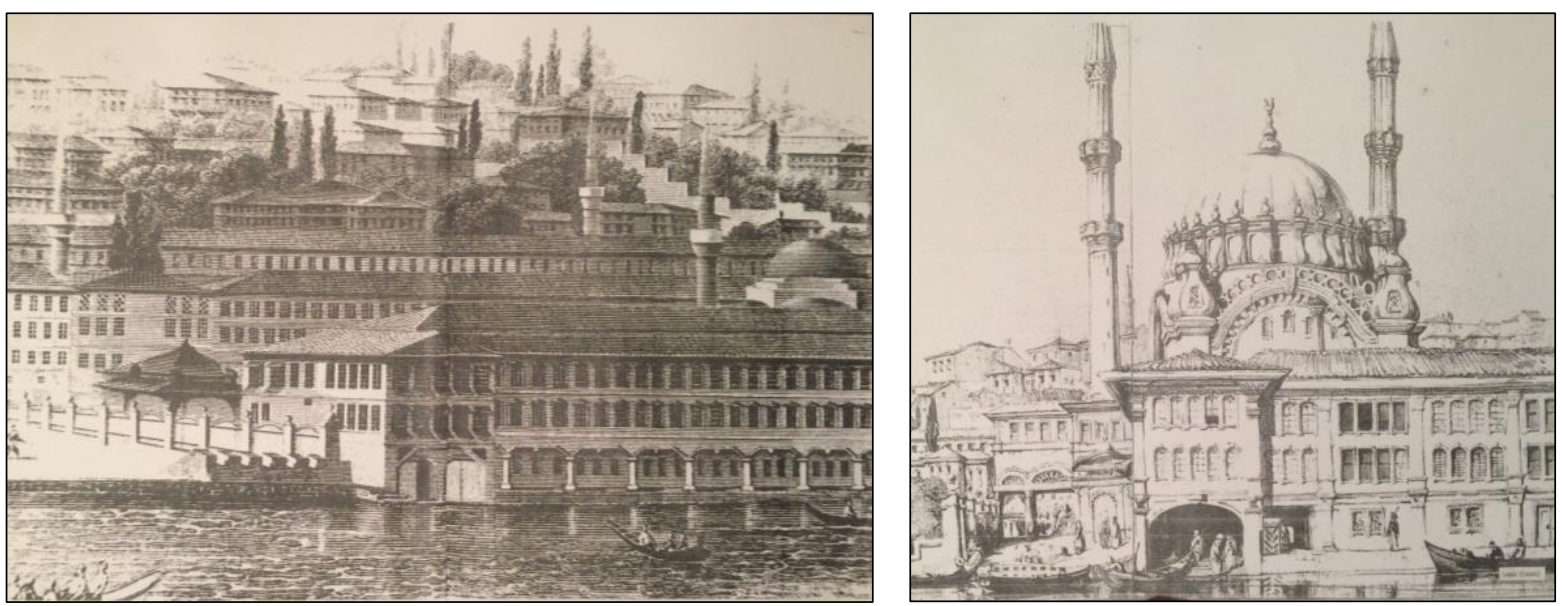

Image 7: Detail (left) (Gülersoy,1971)

Image 8: Nusretiye Mosque and Tophane Barracks details - Leewis drawing (right) (Gülersoy,1971)

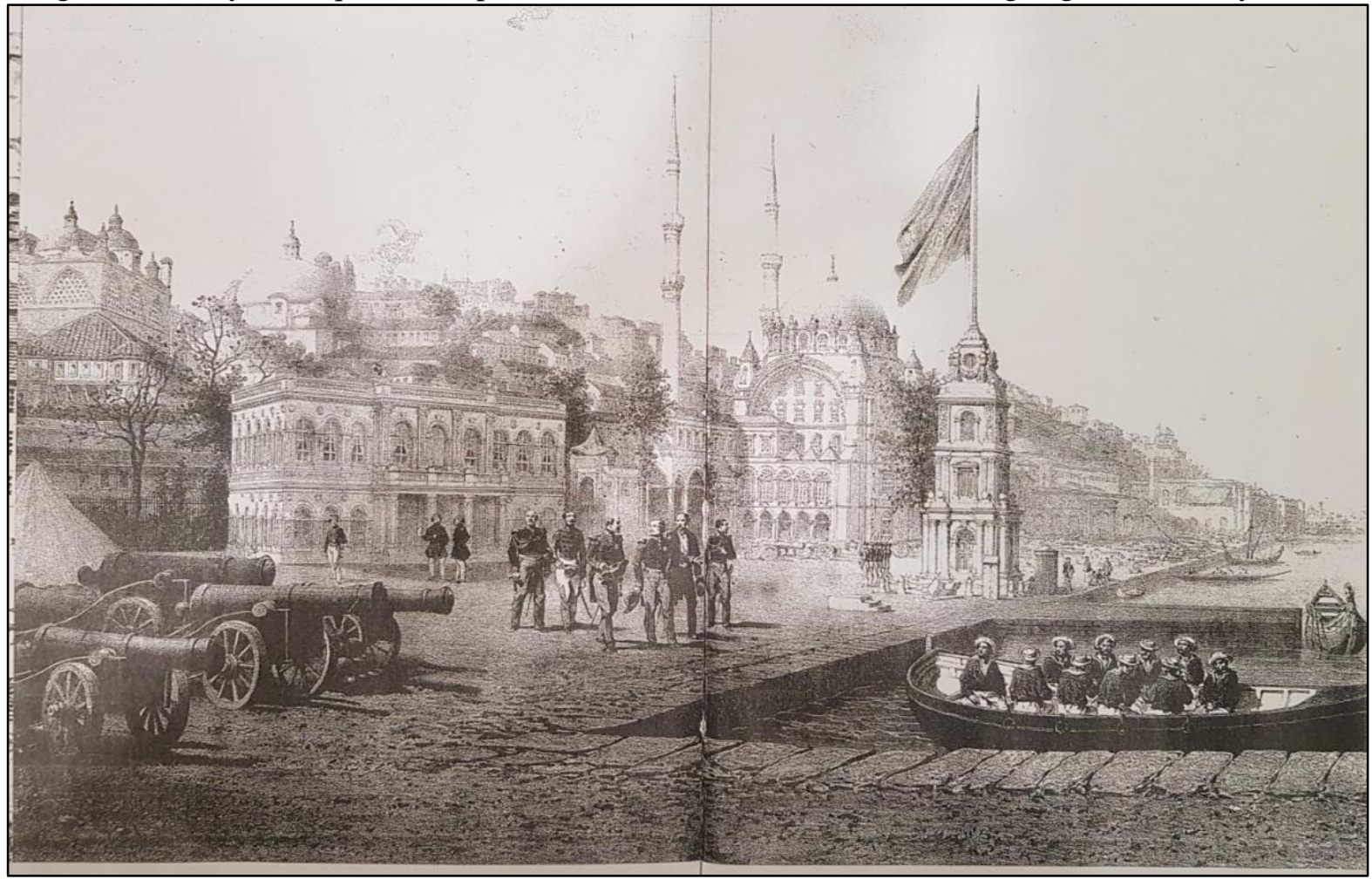

Image 9: Nusretiye Clock Tower (Gülersoy,1971) 

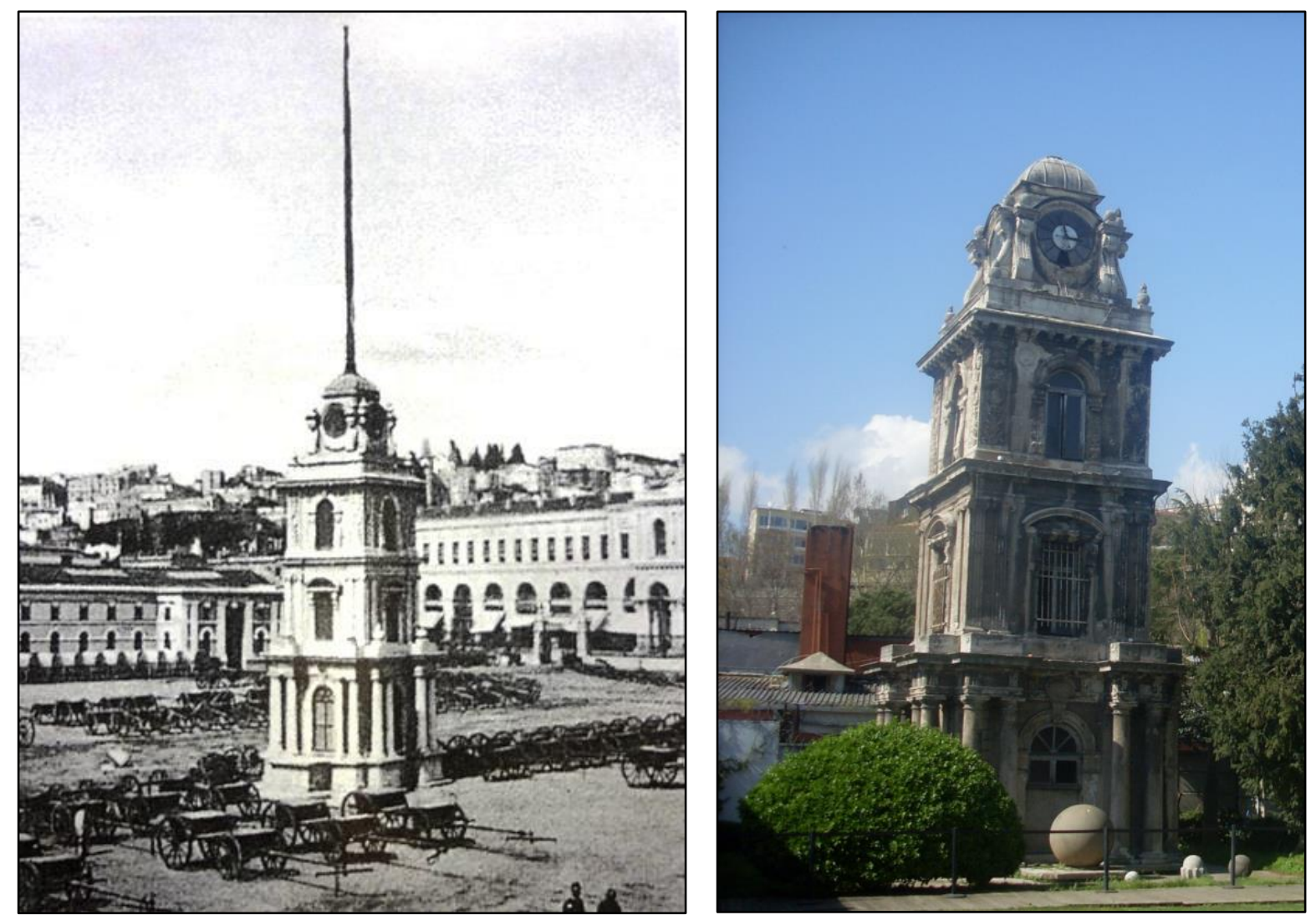

Resim 10: Old and new version of Clock Tower [2] [3]

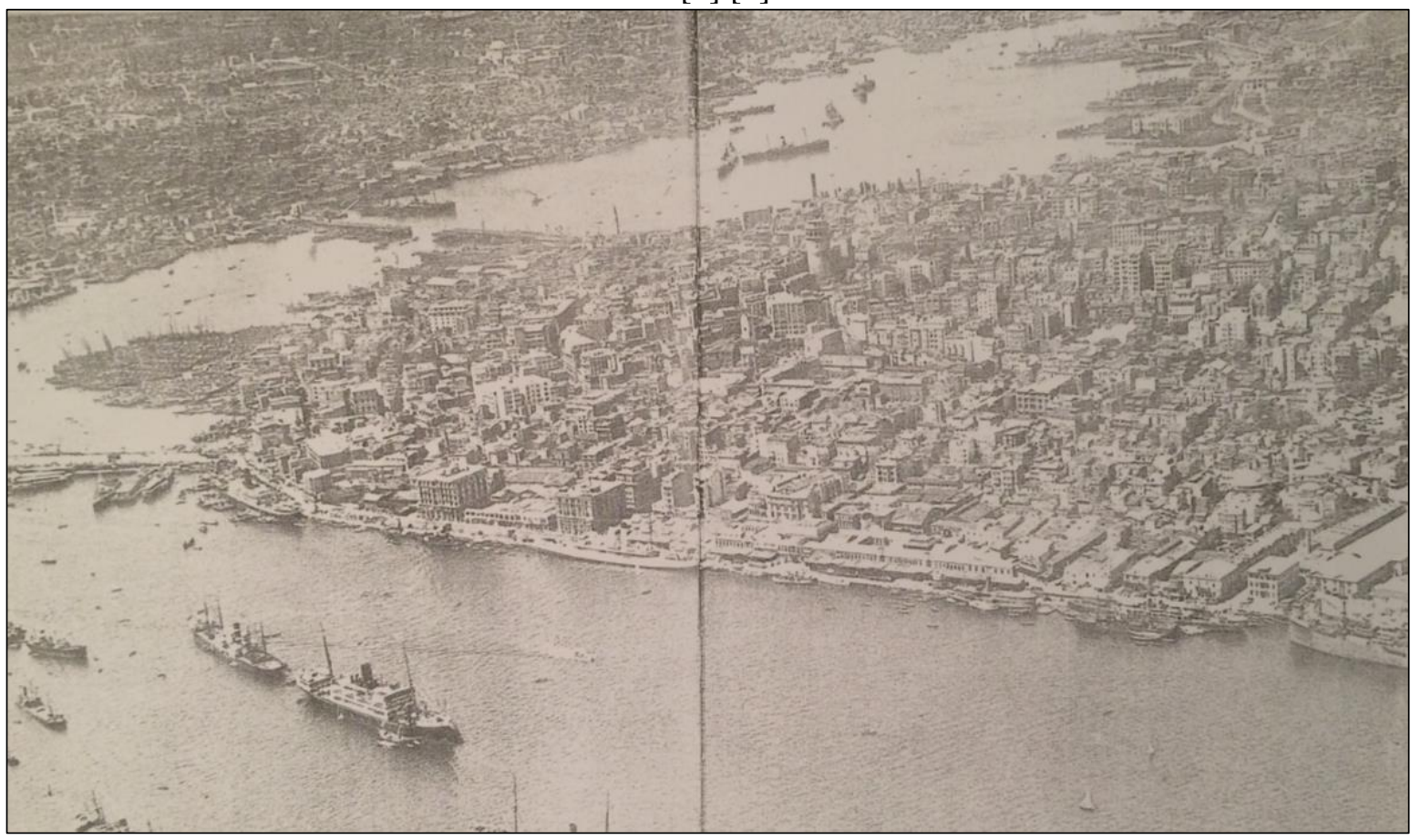

Resim 11: Tophane's appearance in 1923 (Gülersoy,1971) 

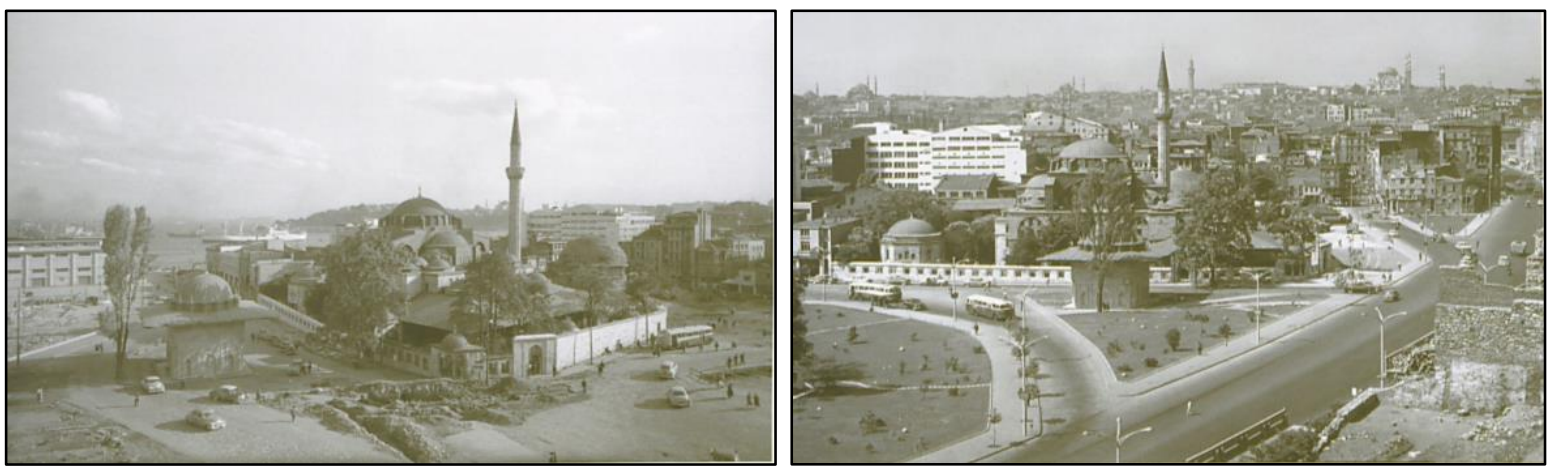

Resim 12: Tophane in 1958 (left) - The end of the 1960(sağda) (Güncüoğlu, 2009: 55)

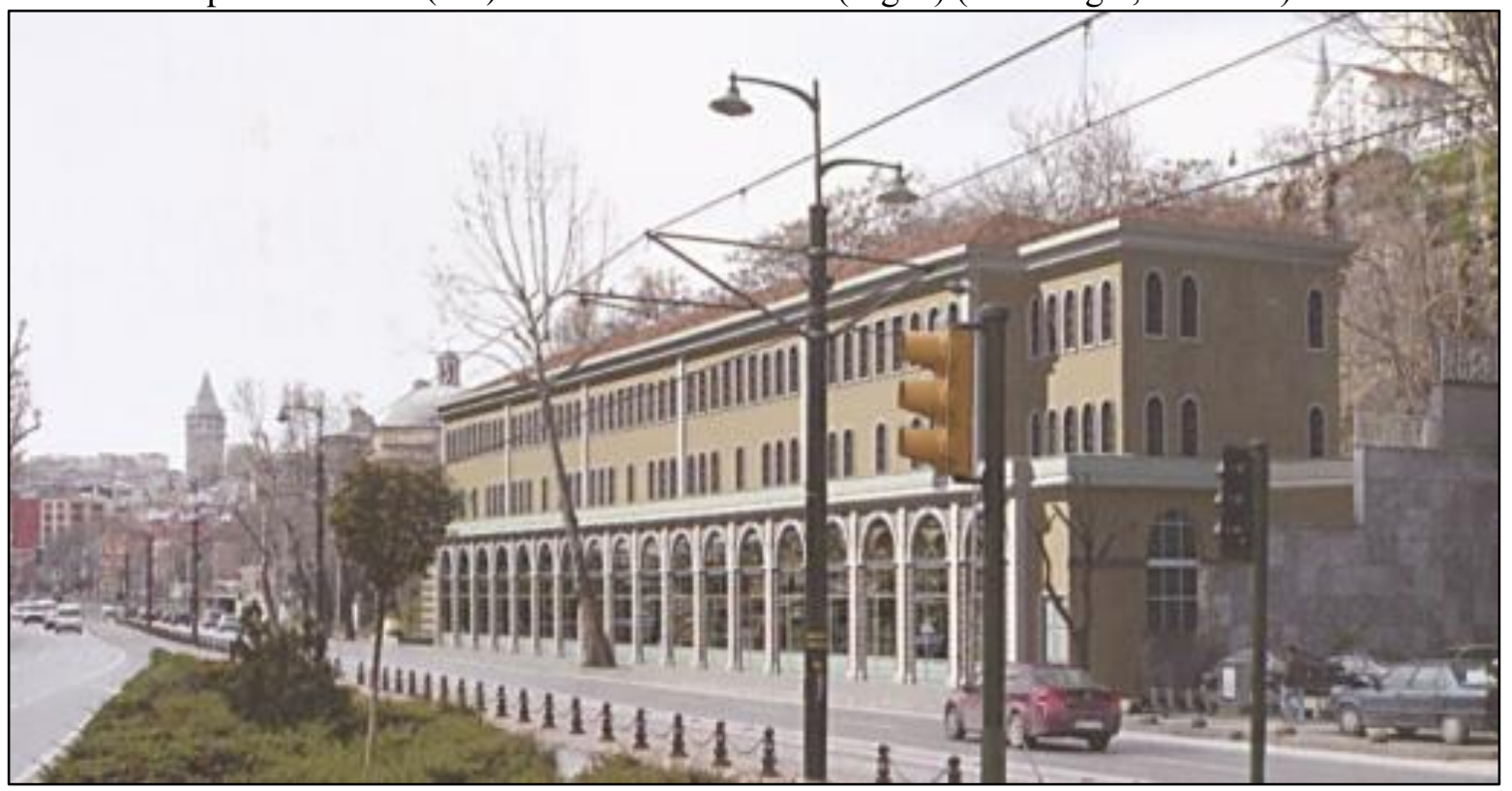

Image 13: Yenileme alanı olarak ilan edilen İmalat-1 Harbiye Usta Mektebi'nin günümüzde yapılmış halini öngeren 3d çalışması (Güncüoğlu, 2009: 69)

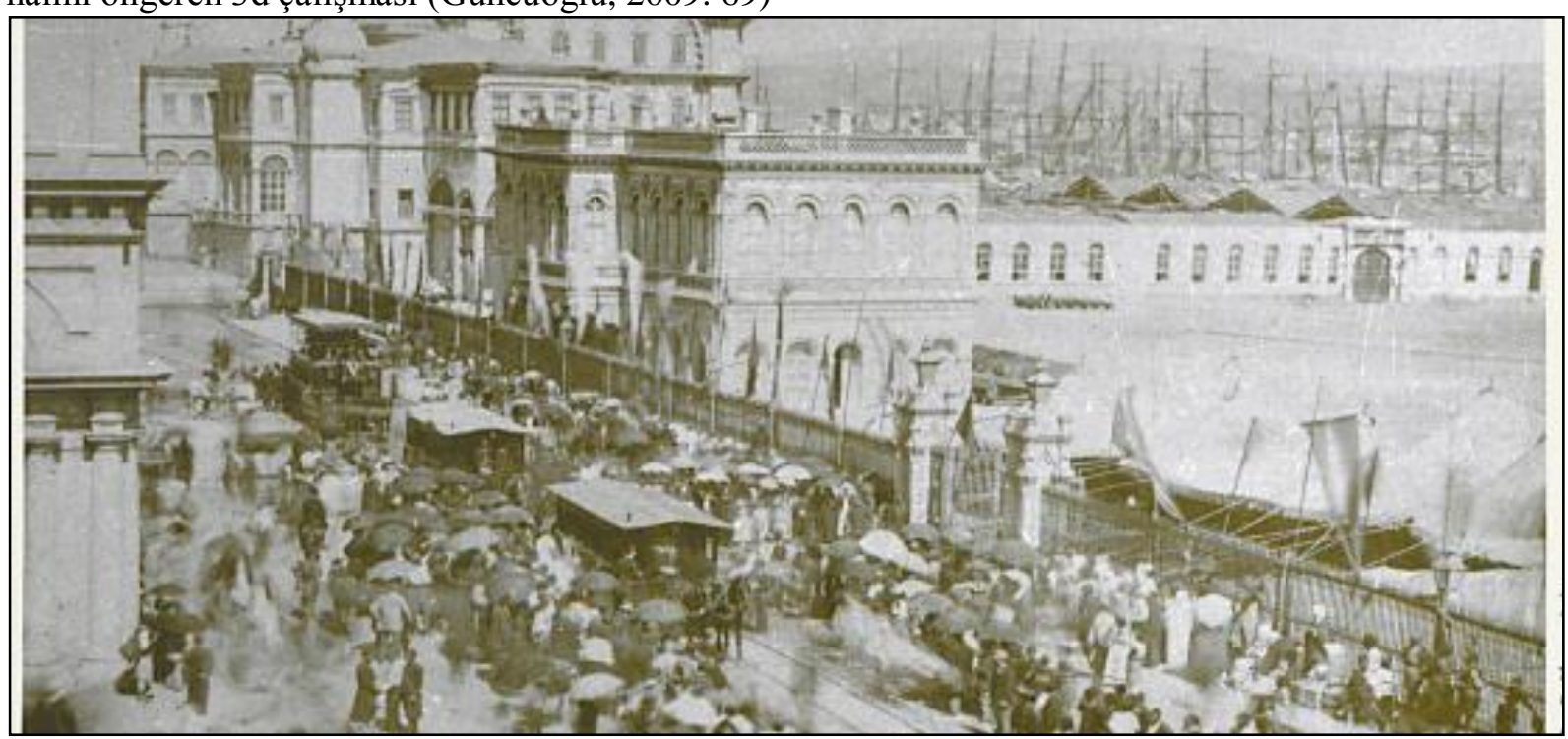

Image 14: Tophane Bazaar and Nusretiye Mosque, the first carriage tram started to service with the ceremony on September 3, 1863, (Güncüoğlu, 2009, s.13) 


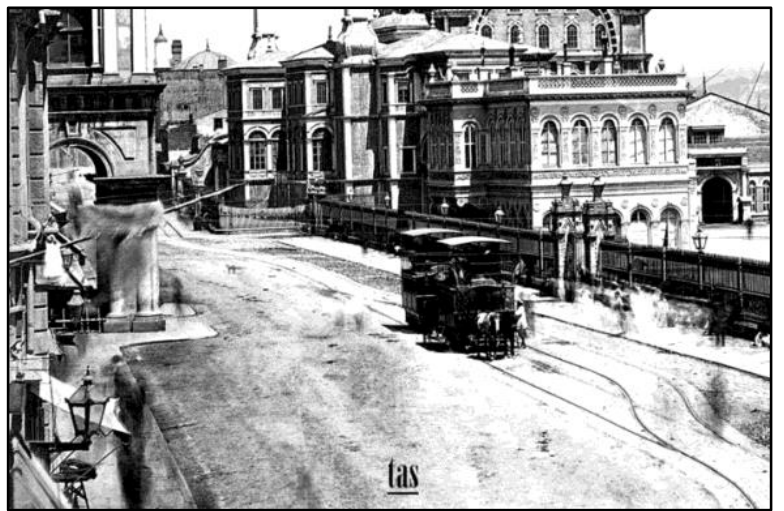

Image 15: Carriage tram [4]

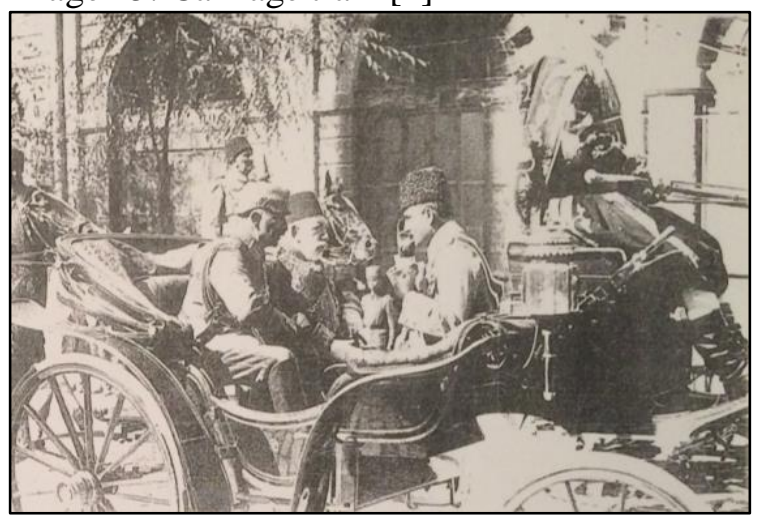

Image 17: Sultan Reşat and Emperor of Germany 2. Willhelm (left) (Gülersoy, 1971) Image 18: Mustafa Kemal Atatürk's funeral (right) (Gülersoy,1971)

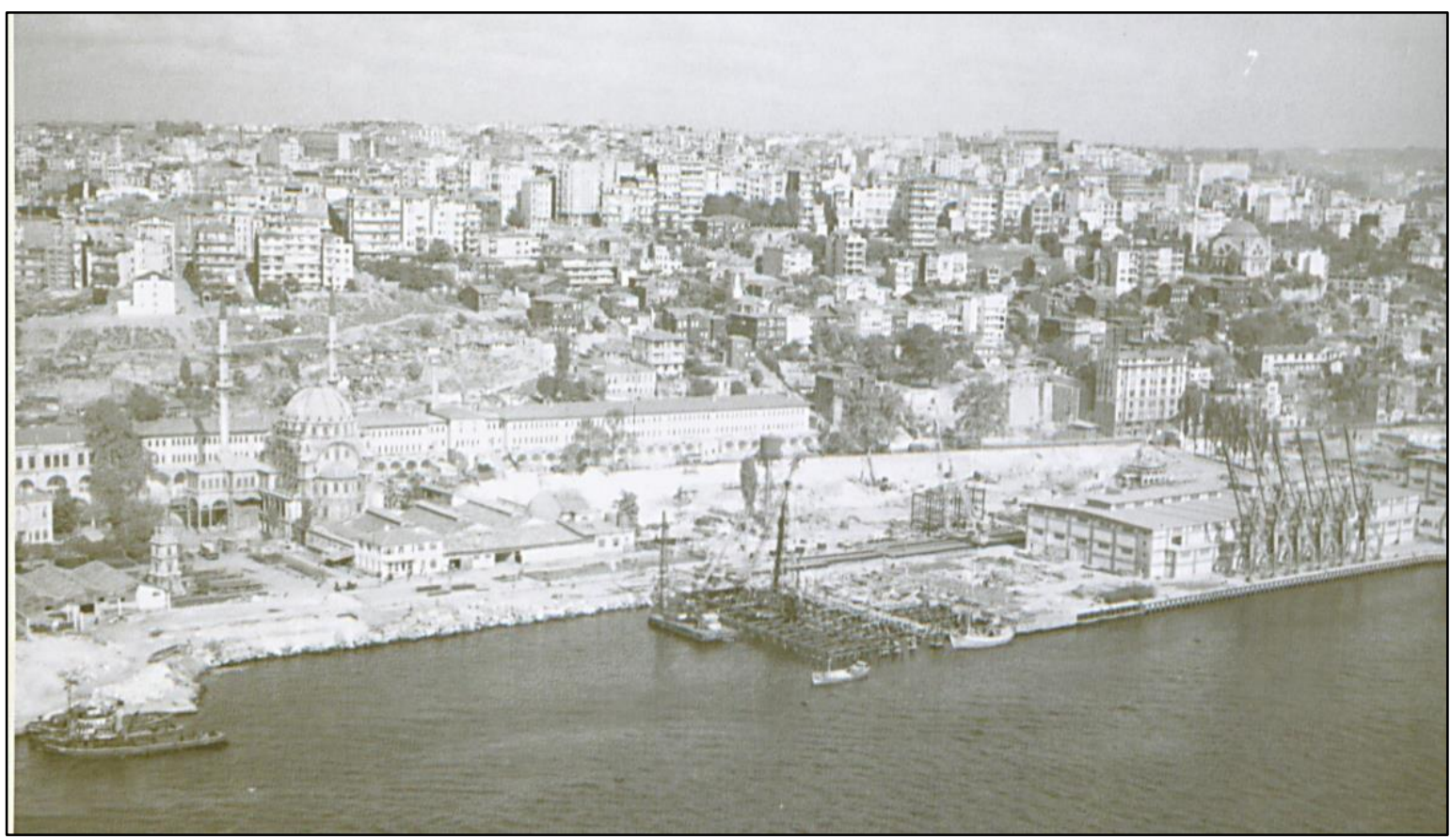

Image 19: Construction of customs buildings on the coast (1950-1953) (Güncüoğlu, 2009, s.38) 
The Turkish Online Journal of Design, Art and Communication - TOJDAC ISSN: 2146-5193, January 2018 Volume 8 Issue 1, p.79-96
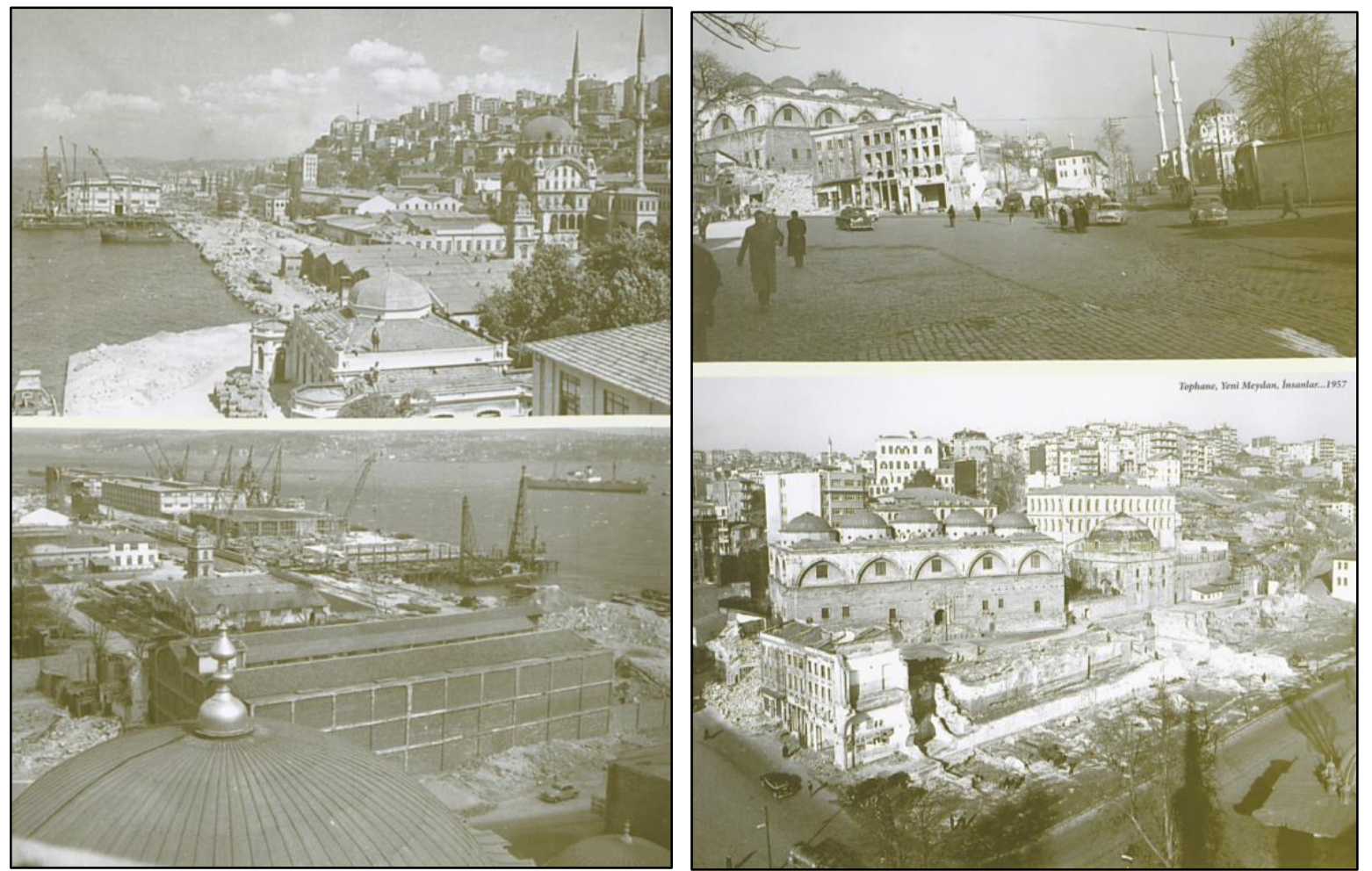

Image 20: The photographs on the left show the destruction of the 1953-54 shore, and the photographs on the right show the destructions that were applied in 1957.

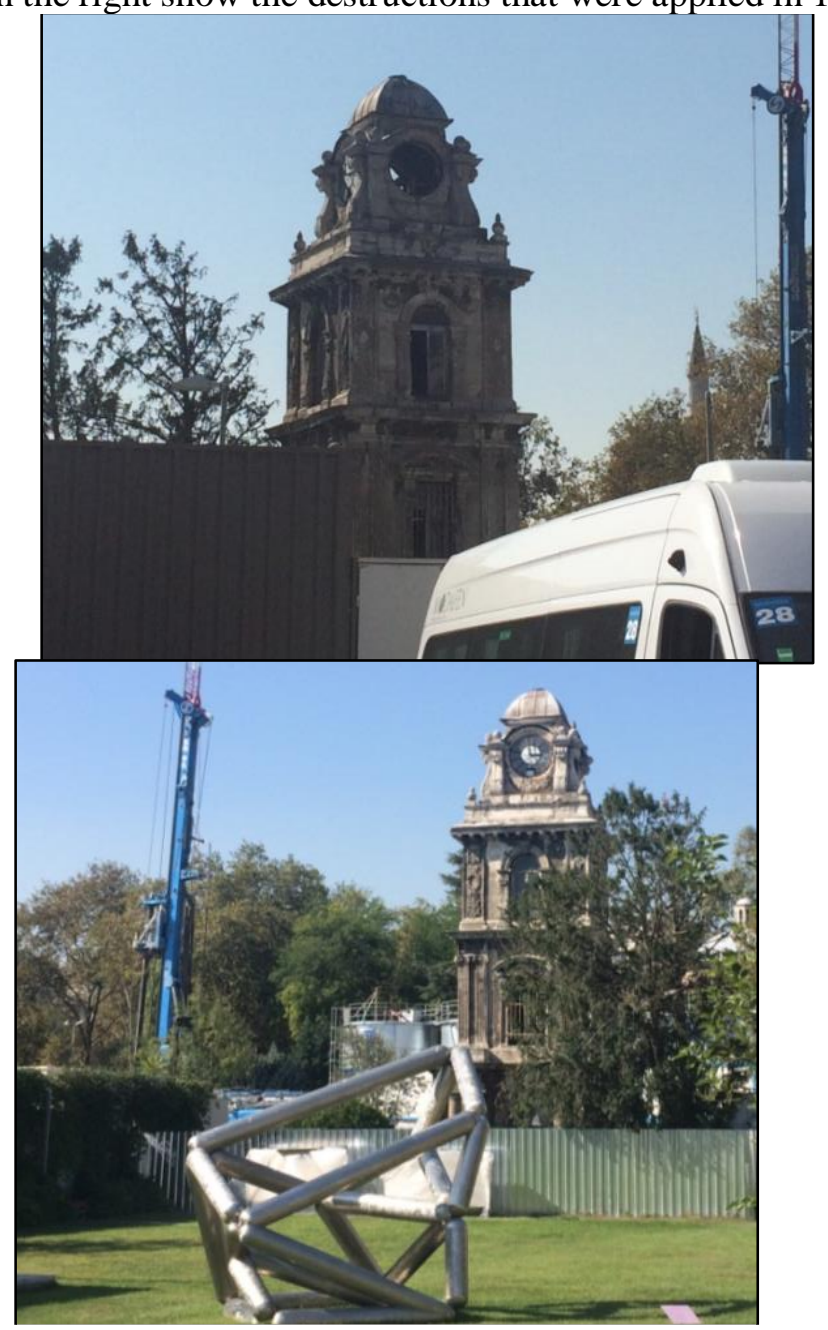

Submit Date: 07.11. 2017, Acceptance Date: 12.12.2017, DOI NO: 10.7456/10801100/008

Research Article - This article was checked by Turnitin

Copyright $\odot$ The Turkish Online Journal of Design, Art and Communication 


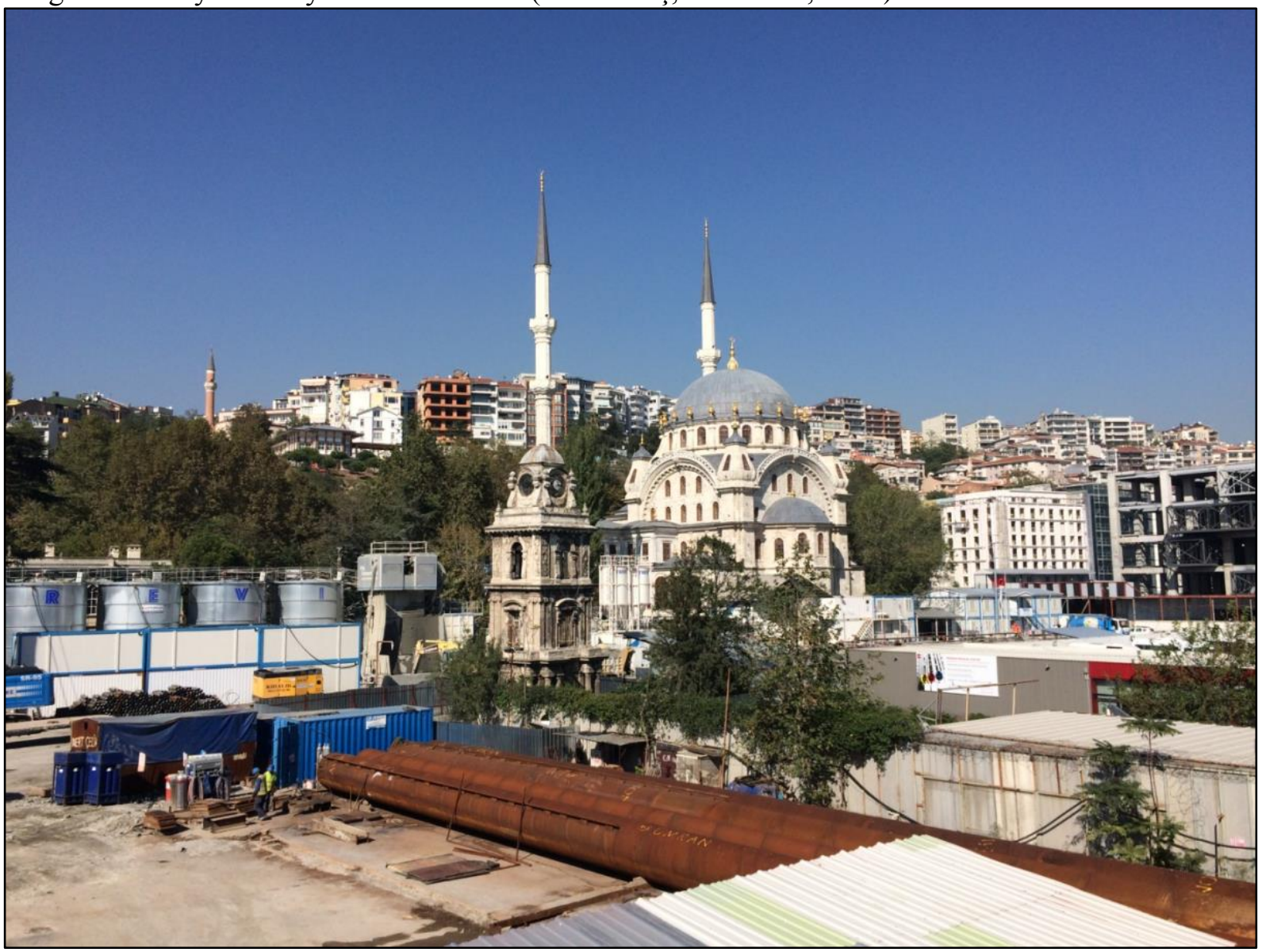

Image 22: Today Nusretiye Clock Tower 2 (M.Altıntaş, E.Gelmez, 2017)

\section{REFERENCES}

Akbulut, A. Ziya, (2010), Güneş Saatleri Yapım Kılavuzu, İstanbul: Biryıl Kültür Sanat Ltd. s.28.

Aktay, Aydın, (2013). Kentsel Mekanın Paylaşılması Sorunu: Tophane Örneği, Doktora Tezi, Sakarya Üniversitesi, Sakarya

Aran, Ahmet, (1995). " Tophane-i Amire", Dünden Bugüne İstanbul Ansiklopedisi, İstanbul: Tarih Vakfi, C:3 ,s.278-280

Aydemir, Işık, (2008). "İki Fransız Mimarı Henri Prost ve August Perret'nin İstanbul İle İlgili Çalışmaları", Megaron Dergisi, C: 3, Sayı: 1, s. 104-111

Aydüz, Salim, (2006). 15. ve 16. Yüzyılda Tophane-i Amire ve Top Döküm Teknolojisi, Ankara: Türk Tarih Kurumu Yayınları.

Aydüz, Salim, (2011a). 'Osmanlı Silahları, Silah Üretim Merkezleri ve Literatürü Tarihi'’, Tarih Okulu, Sayı 10 , s.1-37

Aydüz, Salim, (2011b). 'Osmanlı Askeri Tarihi /Tophane-i Amire ve Osmanlılarda Top Dökümü', Bilim ve Sanat Vakfı Türkiye Araştırmaları Merkezi, Notlar 23, s.21-54

Bir, A. ve Kaçar, M. , (2009). " Güneş Saatlerinin Tarihçesi ve Türleri", Zamanın Görünen Yüzü Saatler, İstanbul: Yap1 Kredi Yayınları, s.17-26.

Büyükcivelek, A.Burak, (2012). " Meydan-Kent Meydanı', Melih Ersoy (der.), Kentsel Planlama Ansiklopedik Sözlük, İstanbul: Ninova Yayınları, s.342-345.

Cansever, Meltem, (2009). "Türkiye'nin Kültür Mirası 100 Saat Kulesi", İstanbul: NTV Yayınları Ceylan, Oğuz, (2003). 'Top Döküm Binaları (Tophane-i Amire) ve Onarımları", ICOMOS TürkiyeYunanistan 2.Ortak Toplantısı Seminer Bildirisi/ Tasarım+Kuram Dergisi, İstanbul: Sayı:3, s.43-56 Ertem, B ve Altunel M.C., (2011), "İstanbul İmarındaki Tarihi Eser Kaybının Tarih ve Turizm Açısından İncelenmesi: Karaköy - Kabataş Bölgesi", ODTÜ Sosyal Bilimler Enstitüsü Sosyal Bilimler Araştırmaları Dergisi, C: 2, Sayı: 4, s.61-79 
Esmer, Mine, (2013). "1956-1960 Karaköy Beşiktaş Sahil Aksında Kaybolan/ Yıkılan/ Taşınan Binalar", Mimarlık Dergisi, Kasın-Aralık 2013, Mimarlar Odası Adına Yayın Komitesi,

Gülersoy, Çelik, (1971). İstanbul: Aspects, a Travers les Epoques, Milano: Interrepro S.R.L,

Güncüoğlu, S.Faruk (2009). Bir Semt-i Meşhur Tophane Değişimin Hikayesi, İstanbul: İstanbul Şehri Kültür Tarihi Araştırma Merkezi.

Gürbüz, Şule , (2009a). " Alaturka Saat, Alaturka Zaman, Zamanın Görünen Yüzü Saatler, İstanbul: Yap1 Kredi Yayınları, s.57-66).

Gürbüz, Şule , (2009b). " Saat Kulelerinin Varlığu ve Yokluğu Üzerine", Zamanın Görünen Yüzü Saatler, İstanbul: Yapı Kredi Yayınları, s.133-147.

Hakk1, Acun, (1994). Anadolu Saat Kuleleri, Ankara: Atatürk Kültür, Dil, ve Tarih Yüksek Kurumu Atatürk Kültür Merkezi Yayını.

Hakk1, Acun, (2011). Osmanlı İmparatorluğu Saat Kuleleri, Ankara: Atatürk Kültür, Dil, ve Tarih Yüksek Kurumu Atatürk Kültür Merkezi Yayını

İnce, Elif, (2013). "Tophane İhyasnda Son Söz Üniversitede", Radikal Gaztesi, 3 Ağustos 2013

Koca, N., Yasemin, (2015). "Yıldızları Yakalamak: Usturlabın Denizcilikte Kullanımı ve Günümüze Ulaşan Örnekleri", Journal of ETA Maritime Science, 3(1), s.11-22

Meyer, Wolfgang, (2009). " İslamiyetteki Güneş Saatleri", Zamanın Görünen Yüzü Saatler, İstanbul: Yapı Kredi Yayınları s.27-31.

Salman, Barış, (2009). " Saatin Eski Çağlardaki Teknolojisi: Güneş ve Su Saatleri", Zamanın Görünen Yüzü Saatler, Yapı Kredi Yayınları s.17-26.

Tunç, Şafak., (2004). Tophane-1 Amire ve Osmanlı Devletinde Top Döküm Faaliyetleri, İstanbul: Başak Kitap

\section{Websites}

[1] http://www.tdk.gov.tr/index.php?option=com_gts\&kelime=MEYDAN

[2] http://www.degisti.com/wp-content/uploads/2012/09/tophane_saat_kulesi_eski.jpg

[3] http://www.istanbulkulturturizm.gov.tr/sites/default/files/styles/1600/public/tophane_nusretiye_saat _kulesi.jpg?itok=HQoggQQQ

[4] http://www.tas-istanbul.com/portfolio-view/tophane-meydani-10/ 